\title{
SOCIAL CLASS VARIATIONS IN MORTALITY
}

\author{
BY \\ W. P. D. LOGAN \\ General Register Office, London
}

An analysis has recently been published of mortality in England and Wales in 1950 by what are customarily called the Registrar-General's "Social Classes" (Registrar-General, 1954).

Social Classes.-The basic unit of the social class grouping is the occupational group. Every occupation in the country, of which there are many thousands, is assignable to one or other of 586 occupational unit groups (General Register Office, 1951). These 586 occupational groups are each assigned as a whole to one or other of five social classes (Table I), on the basis of the predominant characteristics of the majority of the persons in the unit group. The general implication is that classes so composed will reflect the differing social make-up and environment normally associated with persons within those occupational categories. The social class grouping is thus not a classification of individuals, and in assigning an individual to the appropriate social class no account is taken of personal circumstances other than occupation. Having established the occupation, the social class grading follows automatically. Moreover, as well as ignoring individual circumstances other than occupation, the social classification, in treating the occupational group as a whole, makes no special provision for particular occupational minorities within the group, that might, if considered by themselves, qualify for a different grading from that to which their occupational group as a whole has been assigned.

Accordingly, having determined an individual's occupation, the group to which that occupation belongs is immediately established, and the occupational group as a whole is assignable automatically to one or another of the five social classes. For instance, if John Jones is a plumber's mate, the

TABLE I

PERCENTAGE DISTRIBUTION OF OCCUPIED AND RETIRED MEN AGED 15 AND OVER BY FIVE SOCIAL CLASSES. (ENGLAND AND WALES 1951 CENSUS, 1 PER CENT. SAMPLE)

\begin{tabular}{|c|c|c|c|c|}
\hline Social Class & \multicolumn{3}{|c|}{ Occupations } & $\begin{array}{r}\text { Percentage } \\
\text { Distribution }\end{array}$ \\
\hline$\underset{\text { III }}{\text { II }}$ & $\begin{array}{l}\text { Professional, etc. } \\
\text { Intermediate } \\
\text { Skilled } \\
\text { Partly-Skilled } \\
\text { Unskilled .. }\end{array}$ & $\begin{array}{l}\because \\
\therefore \\
\therefore\end{array}$ & $\begin{array}{l}\ldots \\
\because \\
\therefore\end{array}$ & $\begin{array}{r}3 \cdot 3 \\
15 \cdot 0 \\
52 \cdot 7 \\
16 \cdot 2 \\
12 \cdot 8\end{array}$ \\
\hline \multicolumn{2}{|c|}{ Total All Classes, $15,467,700$} & .. & .. & 100 \\
\hline
\end{tabular}

classification of occupations shows that he belongs to Occupational Group No. 201 (Plumbers' Labourers), and the classification also shows that this occupational group as a whole belongs to Social Class IV (Partly Skilled Occupations). On the other hand had he been a plumber and jointer's mate he would have belonged to Occupational Group No. 940 (Labourers and other Unskilled Workers in Metal Working, Engineering, Electrical, and Allied Trades), and the whole of this very large group is assigned to Social Class V (Unskilled Occupations).

\section{Development of Occupational and Social Class Mortality Studies}

As the social classes are constructed on the basis of an occupational classification, the study of social class mortality variations is a development from the study of mortality in individual occupational groups. It is just over 100 years since the first official study of occupational mortality in Great Britain was undertaken. This was an analysis (Tablee II) of deaths from all causes in 1851 in severa hundred occupations, related to the populations of these occupations as determined by the 1851 Census (Registrar-General, 1855). Similar studies were made of deaths in 1860-61 in relation to the 1861 Census, and thereafter at 10-year intervals in or around each successive Census year, standardized death rates being introduced to allow for differences in the age structure of different occupations, and separate causes of death studied. In 1910-12 the occupational mortality analysis distinguished 132 occupational groups and 27 causes

TABLE II

MORTALITY PER 1,000 MALES AGED 45-54 IN SELECTED OCCUPATIONS (ENGLAND AND WALES, 1851)

\begin{tabular}{|c|c|c|c|c|c|}
\hline \multicolumn{5}{|c|}{ Occupation } & Death Rate \\
\hline $\begin{array}{l}\text { Farmer } \\
\text { Shoemaker } \\
\text { Weaver } \\
\text { Grocer } \\
\text { Blacksmith } \\
\text { Carpenter } \\
\text { Tailor } \\
\text { Labourer } \\
\text { Miner } \\
\text { Baker } \\
\text { Butcher } \\
\text { Inn-keeper }\end{array}$ & $\begin{array}{l}\cdots \\
\cdots \\
\cdots \\
\cdots \\
\cdots \\
\cdots \\
\cdots \\
\cdots\end{array}$ & $\begin{array}{l}\ldots \\
\cdots \\
\ldots \\
\cdots \\
\cdots \\
\cdots \\
\cdots \\
\cdots\end{array}$ & $\begin{array}{l}\ldots \\
\cdots \\
\cdots \\
\cdots \\
\cdots \\
\cdots \\
\cdots \\
\cdots\end{array}$ & $\begin{array}{l}\cdots \\
\cdots \\
\cdots \\
\cdots \\
\cdots \\
\cdots \\
\cdots \\
\cdots\end{array}$ & $\begin{array}{l}11 \cdot 99 \\
15 \cdot 03 \\
15 \cdot 37 \\
15 \cdot 79 \\
16 \cdot 51 \\
16 \cdot 67 \\
16 \cdot 74 \\
17 \cdot 30 \\
20 \cdot 15 \\
21 \cdot 21 \\
23 \cdot 10 \\
28 \cdot 34\end{array}$ \\
\hline \multicolumn{2}{|c|}{ All Occupations } & . & . & . & $17 \cdot 87$ \\
\hline
\end{tabular}


of death at ages 25-64 (Registrar-General, 1923). In this analysis, and also in a study of infant mortality in 1911 (Registrar-General, 1913), the various occupations were for the first time grouped together into Social Classes, of which on this occasion there were eight (Table III). The first five were graded in much the same way as in Table I, but three important occupational groups were kept apart and classed separately as Social Classes VI, VII, and VIII (Stevenson, 1923).

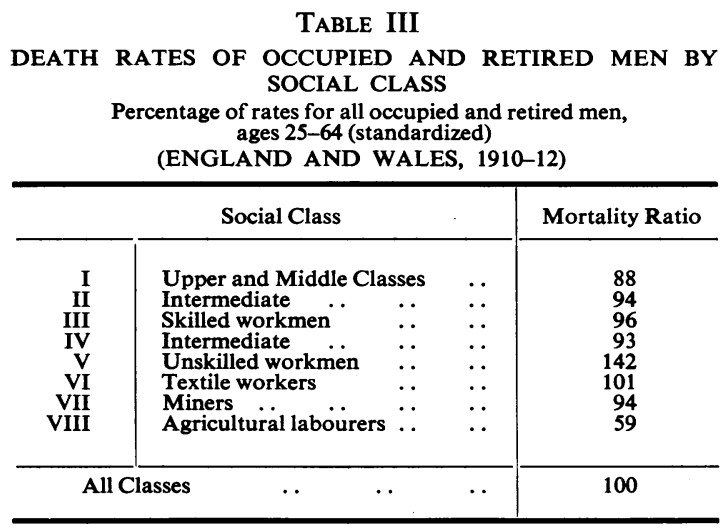

In 1921-23 (Registrar-General, 1927), deaths were tabulated for forty causes in 164 occupational groups, the occupational classification being considerably improved and made more properly occupational as distinct from industrial as it had previously tended to be. Five Social Classes only were distinguished, Classes VI to VIII of the previous classification being merged with the others (Stevenson, 1928).

We come now to the most recent occupational mortality analysis, that for the years 1930-32 (Registrar-General, 1938). For males this was on the same lines as before, but with further details of causes of death and of occupations. A new departure was the study of the mortality of single women classified by their own occupations, and of married women classified by the occupation of the husband. There are some special difficulties in studying the occupational mortality of single women. For example, many are unoccupied or are only transitorily in employment-and it was because of these difficulties that they had not previously been included; and I should not like to claim that their inclusion in 1930-32 has really got us very far.

Analysing the mortality of married women according to the husband's occupation was, however, a great step forward. It has allowed comparison between the mortality of men in particular occupations and of their wives who generally share the same socio-environmental circumstances as the husbands but are not usually exposed to their occupational hazards or disadvantages. It thus became possible in 1930-32 to begin to distinguish between mortality risks that were primarily of occupational origin (though not necessarily due to direct occupational hazards), and those arising rather from the socio-economic environments in which people in various kinds of occupations tend to live (Stocks, 1938).

Limitations of this Method of ENQUiRy.-There are well-recognized limitations in the study of occupational mortality, and, to a less extent in that of social class mortality, by the method traditionally employed-which depends upon relating occupational information obtained at death registration to occupational information derived from the Census. These limitations have been discussed in great detail in the various official reports and only two will be mentioned here.

One type of error can arise from differences between the occupational description given by an individual himself on the Census schedule and that given by a relative when registering his death. The individual probably knows best what his occupation really is, but may not describe it properly or in sufficient detail on the Census schedule; whereas when a death is registered the Registrar is in a position to elicit details, including information about the previous occupation of a retired person, though occasionally the informant may not have sufficient knowledge to provide the information accurately.

Another type of difficulty arises in attempting to interpret the recorded mortality rates; it then becomes necessary to consider the extent to which an apparently high or low mortality rate recorded for an occupation may be due to physically or medically selective recruitment or discharge. For example the police force may recruit only the physically fit, whereas other types of occupation may attract or become the refuge of invalids or persons of poor physique. The recorded mortality rates for such occupations might reflect the type of people engaged therein more than the risks of the occupation itself. Furthermore, the recorded mortality rate of a dangerous or physically onerous occupation may be understated, owing to persons in failing health transferring themselves to a less exacting job some time before death.

STUDIES IN OTHER Countries.-In this field of occupational and social class mortality studies work has been done in England and Wales on a much larger scale than elsewhere. A valuable survey of 
what has been done in various countries has been given by Daric (1949), from whom some of the following information has been taken.

Scotland.-Occupational variations in mortality were studied in relation to the Census of 1891 and 1901, and infant mortality and stillbirth statistics by social class have been published for 1939 and annually since 1944 .

France.-Villermé (1840) made a small study of mortality in relation to occupation and social class in Mulhouse during 1823-34; Bertillon (1889) gave some data for Paris in 1885-89; and Huber (1912), in a much more comprehensive study, examined occupational mortality in the whole country for $1907-8$ in relation to the 1906 Census. Table IV is an extract from his findings.

TABLE IV

AVERAGE ANNUAL DEATH RATES PER 10,000 MEN AGED 45-54 IN CERTAIN OCCUPATIONS (FRANCE, 1907-08 [HUBER, 1912])

\begin{tabular}{|c|c|c|c|c|c|c|}
\hline \multicolumn{6}{|c|}{ Occupation } & Rate per 10,000 \\
\hline $\begin{array}{l}\text { Managers } \\
\text { Clerks } \\
\text { Craftsmen } \\
\text { Farmers } \\
\text { Miners } \\
\text { Bakers } \\
\text { Textile wor } \\
\text { Tailors } \\
\text { Plumbers } \\
\text { Physicians } \\
\text { Teachers } \\
\text { Waiters }\end{array}$ & $\begin{array}{l}\text { and of } \\
\text { and } k \\
\ldots \\
\ddot{\text { rkers }} \\
\ldots \\
\text { and p } \\
\ldots \\
\ldots\end{array}$ & $\begin{array}{c}\text { icial } \\
\text { ndre } \\
\ldots \\
\ldots \\
\ldots \\
\ldots \\
\ldots \\
\ldots \\
\ldots\end{array}$ & $\begin{array}{l}\ldots \\
\text { orkers } \\
\ldots \\
\ldots \\
\ldots \\
\ldots \\
\ldots \\
\text { sts } \\
\ldots \\
\ldots\end{array}$ & $\begin{array}{l}\ldots \\
\ldots \\
\ldots \\
\ldots \\
\ldots \\
\ldots \\
\ldots \\
\ldots \\
\ldots\end{array}$ & $\begin{array}{l}\cdots \\
\cdots \\
\cdots \\
\cdots \\
\cdots \\
\cdots \\
\cdots \\
\cdots\end{array}$ & $\begin{array}{l}127 \\
203 \\
232 \\
104 \\
204 \\
306 \\
194 \\
335 \\
493 \\
194 \\
140 \\
343\end{array}$ \\
\hline \multicolumn{4}{|c|}{ Total gainfully occupied } & .. & . & 171 \\
\hline
\end{tabular}

United States of America.-Dublin and Vane (1917, $1930,1947)$ have published studies of the mortality experience of wage-earners insured with the Metropolitan Life Insurance Company. A less restricted study was that of Whitney (1934), in which he related the death registration occupational data from ten States to the 1930 Census enumeration. He grouped the occupations into seven socio-economic classes not dissimilar to those used in England and Wales (Table V).

Switzerland.-Occupational mortality studies were made for the periods 1879-82 and 1891-1900.

Netherlands.-Studies were made for the three periods 1891-95, 1896-1900, and 1908-11.

Alternative Methods of Social Classification.The Registrar-General's Social Classification is an arrangement of occupations into five groups graded not by some precisely measurable attribute but by the less specific but by no means imponderable characteristic of "standing in the community". It would be possible, still retaining occupation as the distinguishing unit, to devise alternative classification by grouping the occupations in other ways. One way could be to grade and group according to their recorded mortality rates. In one sense such a
TABLE V

STANDARDIZED DEATH RATES PER 1,000 OCCUPIED MALES AGED 15-64 IN SELECTED OCCUPATIONS ACCORDING TO SOCIO-ECONOMIC CLASS, AND PER CENT. OF RATE FOR ALL OCCUPIED MALES (UNITED STATES OF AMERICA, 1930 [WHITNEY, 1934])

\begin{tabular}{|c|c|c|c|}
\hline \multicolumn{2}{|r|}{ Socio-economic Class } & $\begin{array}{c}\text { Standardized } \\
\text { death rate }\end{array}$ & $\begin{array}{l}\text { Mortality } \\
\text { Ratio }\end{array}$ \\
\hline $\begin{array}{r}\text { II } \\
\text { III } \\
\text { IV } \\
\text { VI } \\
\text { VII }\end{array}$ & 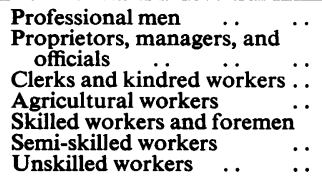 & $\begin{array}{r}6 \cdot 7 \\
7 \cdot 9 \\
7 \cdot 8 \\
6 \cdot 2 \\
8 \cdot 3 \\
10 \cdot 1 \\
14 \cdot 5\end{array}$ & $\begin{array}{r}74 \\
87 \\
87 \\
68 \\
91 \\
111 \\
159\end{array}$ \\
\hline & $\begin{array}{l}\text { All gainfully occupied males in } \\
\text { selected occupations }\end{array}$ & $9 \cdot 1$ & 100 \\
\hline
\end{tabular}

procedure would be absurd, since it would yield not a gradient of social classes but of mortality classes, and could not be used legitimately to demonstrate correlation between mortality and social class defined independently of mortality; but for certain purposes, as for instance occupational standardization of local rates, such a classification might be better than any other.

A new grouping of occupations that has been included in the 1951 Census One per cent. Sample Tables (Registrar-General, 1952) comprises thirteen socio-economic groups. This classification has been used for the tabulation of fertility and of households (Table VI, opposite), but not yet in connexion with mortality.

A quite different type of occupational reclassification, unrelated to social criteria, was used recently by Morris and Heady (1953), who compared the mortality in 1930-32 from certain causes amongst men, classifying their occupations by the amount of physical activity involved, viz. heavy workers, intermediate and doubtful, and light workers. A further classification, introduced only for research into cancer of the lung, was "smoking possible" and "smoking prohibited".

Various other groupings of occupation could be devised on the basis of other criteria deemed likely to yield a social differentiation, as for instance, the attachment to each occupation of some estimate of its average level of education, income, housing standards, and the like.

Putting occupation aside, the criteria just instanced could themselves be used as the units of classification; that is to say, individuals might be classified not by occupation but directly by their individual level of education, income, housing, etc. Unfortunately the practical difficulties are great: dependable information would not be forthcoming from the Census and would have to be obtained otherwise, while questions 
TABLE VI

PERCENTAGE DISTRIBUTION OF HOUSEHOLDS CLASSIFIED BY SOCIO-ECONOMIC GROUP OF HEAD OF HOUSEHOLD. (ENGLAND AND WALES. 1951 CENSUS 1 PER CENT. SAMPLE)

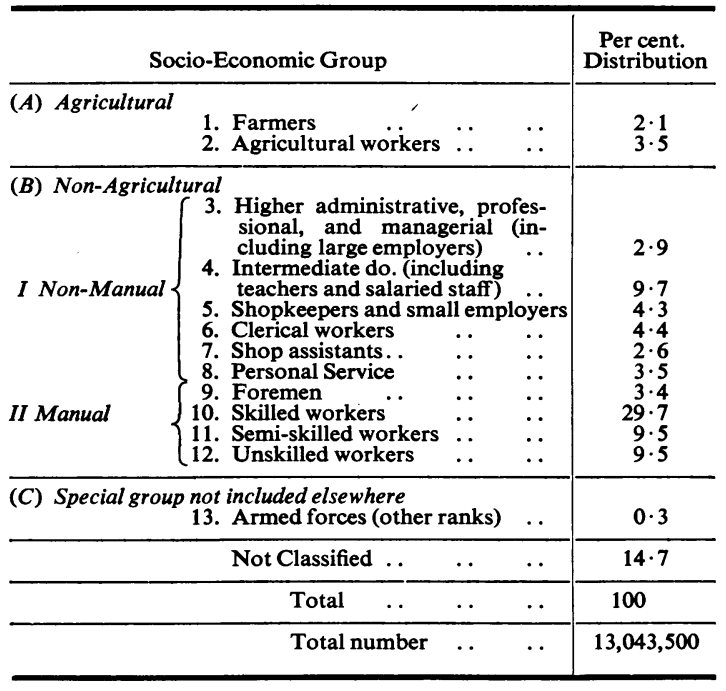

about education and housing, and still less about income, would not be answered accurately and would be inappropriate at death registration.

Though it is admittedly imperfect, it will not be easy to find a more practically convenient criterion than that of occupation.

There is, however, another widely-used though rather crude unit of classification, namely area of residence. This has the advantage, like occupation, of being an item of information about the individual that is entered both on registration and census records. Using this criterion, all the individuals living in one area, in a town or part of a town, are classified together as belonging to one particular "social" group, no regard being paid to other circumstances of the individual that might suggest that he did not in fact belong to that group. There is thus a clear resemblance to using whole occupational groups as the unit, regardless of individual discrepancies, but in the case of area the individual discrepancies are likely to be wider and the resulting social classification less sensitive. Having decided upon the use of area as the unit, their allocation to various social groups can be made on the basis of a rough and ready non-specific kind of grading in which, for instance, one might, from general experience, decide to grade Belgravia higher than Pimlico, or Hampstead higher than Kentish Town; or alternatively the grading and grouping of the areas might be made in accordance with some definite and measurable characteristic, such as standard of housing, overcrowding, number of public houses, proportion of the population in certain types of occupation, or even the local mortality rate itself, as was done in some of the early reports of the General Register Office.

Lastly, one further type of classification should be mentioned, which has not yet been used for mortality comparisons, namely classification by industrial status. Here individuals are classified not by occupational group or locality of residence but by their relationship to their trade or employment. Table VII shows the industrial status groupings adopted in the 1951 Census.

\section{TABLE VII}

PERCENTAGE DISTRIBUTION OF MEN AGED 15 AND OVER BY INDUSTRIAL STATUS. (ENGLAND AND WALES, 1951 CENSUS, 1 PER CENT. SAMPLE)

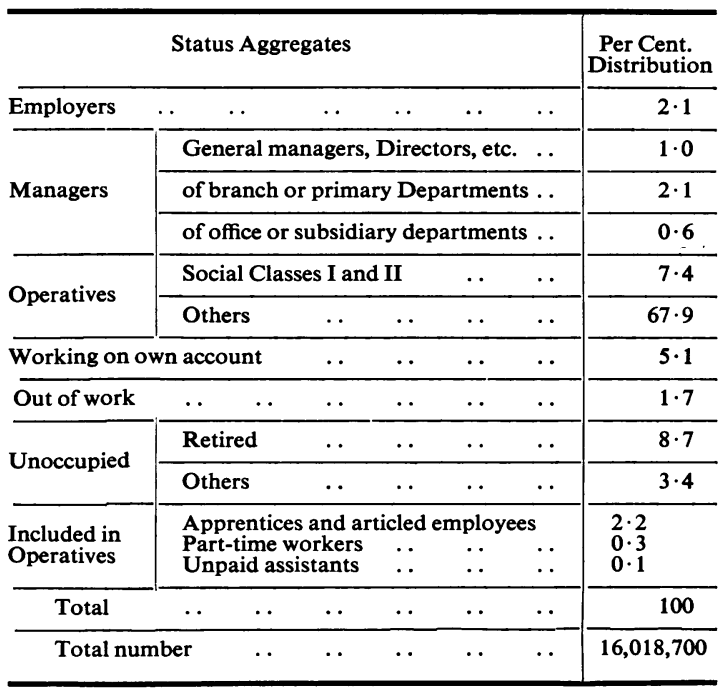

The 1950 AnALYsis

This deals with deaths in 1950 related to the results of the 1951 Census One per cent. Sample, and constitutes a preliminary, and much restricted survey of what we may expect to find in the full analysis which will cover deaths in the 5 years 1949-53, and give greater detail than ever of occupations and of causes of death. Since this full analysis will not be completed for several years, and it is now over 20 years since the last one was made, it seemed desirable to take advantage of the opportunity offered by the One per cent. Sample population data to prepare some advance tables, deliberately limited to the main social classes and some major divisions of these, and to a few of the most important causes of death.

For full details readers should refer to the official report (Registrar-General, 1954). 
Table VIII and Fig. 1 compare the standardized mortality ratios (S.M.Rs) of men aged 20-64 in the five social classes in 1950 with those recorded in 1921-23 and 1930-32.

In 1921-23 and 1930-32 there was an uninterrupted

TABLE VIII

STANDARDIŻED MORTALITY RATIOS OF MEN AND MARRIED WOMEN AGED 20-64 BY SOCIAL CLASS. (ALL CAUSES 1921-23, 1930-32, AND 1950)

\begin{tabular}{c|l|l|l|r|r|r}
\hline \multirow{2}{*}{ Category } & \multirow{2}{*}{ Date } & \multicolumn{5}{|c|}{ Social Class } \\
\cline { 3 - 7 } & & I & II & III & IV & V \\
\hline \multirow{3}{*}{ Men aged 20-64 } & $1921-23$ & 82 & 94 & 95 & 101 & 125 \\
& $1930-32$ & 90 & 94 & 97 & 102 & 111 \\
& 1950 & 97 & 86 & 102 & 94 & 118 \\
\hline $\begin{array}{c}\text { Married women aged } \\
\text { 20-64 }\end{array}$ & $1930-32$ & 81 & 89 & 99 & 103 & 113 \\
& 1950 & 96 & 84 & 101 & 104 & 117 \\
\hline
\end{tabular}
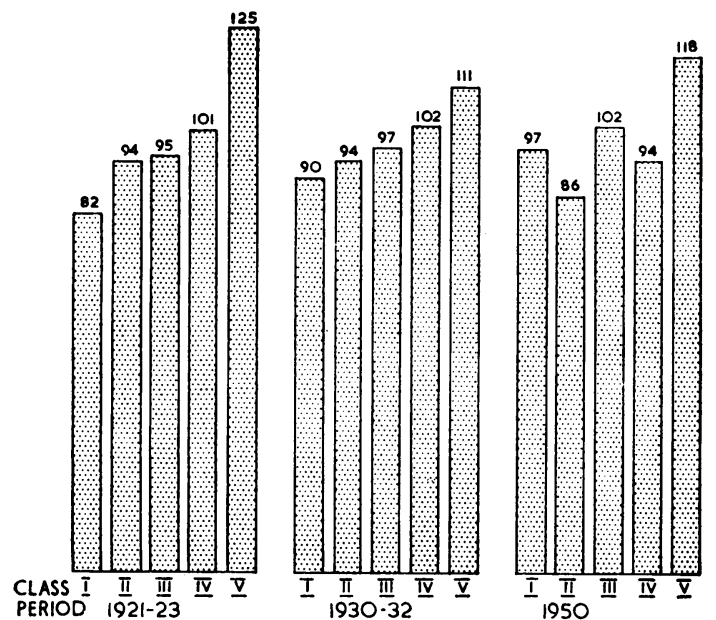

FIG. 1.-Standardized mortality ratios (all causes) of men aged 20-64, by social class. upward gradient of mortality from Social Class I (professional) to Social Class V (unskilled). In 1950 the gradient was much less regular, the lowest ratios being given by Social Classes II and IV. All kinds of suggestions might be made to explain this departure in 1950 from the former regular gradient. But, remembering that the ratios have been calculated with only one year's deaths as numerator and a One per cent. Census Sample as denominator, it would be advisable to await more comprehensive figures before exploring the various possibilities in detail. It is difficult to believe that the irregular trend can have arisen only as a result of random fluctuation in the figures.

The social class mortality gradient for married women (Table VIII and Fig. 2) has also become less regular in 1950 than it was in 1930-32, the only
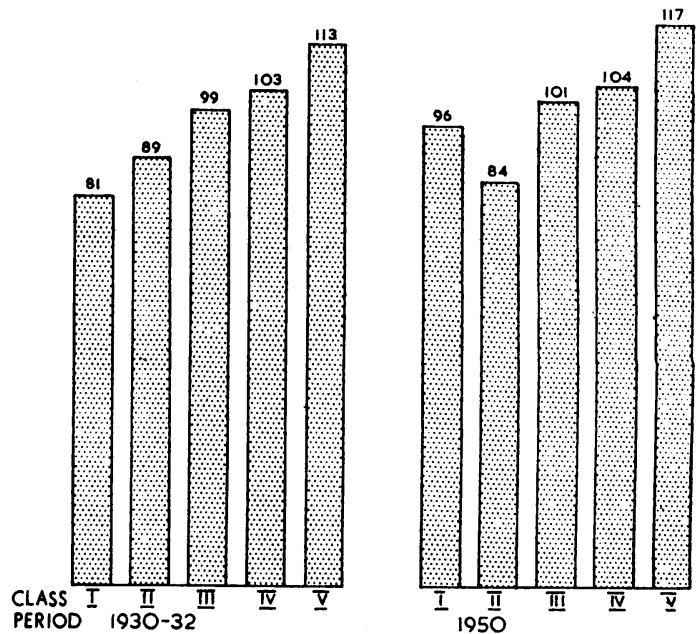

FIG. 2.-Standardized mortality ratios (all causes) of married women aged $20-64$, by social class of husband.

SELECTED DISEASES. STANDARD MORTALITY RATIOS AT AGE 20-64 AND PROPORTIOTATE

\begin{tabular}{|c|c|c|c|c|c|c|c|c|c|c|c|c|c|c|c|c|c|c|}
\hline \multirow{2}{*}{\multicolumn{3}{|c|}{ Disease }} & \multirow{2}{*}{\multicolumn{5}{|c|}{$\begin{array}{l}\text { Respiratory } \\
\text { Tuberculosis }\end{array}$}} & \multicolumn{11}{|c|}{ Cancer } \\
\hline & & & & & & & & \multicolumn{5}{|c|}{ Stomach $\uparrow$} & \multicolumn{5}{|c|}{ Lung } & Brea \\
\hline \multicolumn{3}{|c|}{ Social Class } & I & II & III & IV & v & I & II & III & IV & $\mathrm{v}$ & I & II & III & IV & $\mathrm{v}$ & OII \\
\hline \multirow{5}{*}{ Age $20-64$} & \multirow{3}{*}{ Men } & $1921-23$ & 49 & 81 & 95 & 97 & 137 & 60 & 82 & 100 & 106 & 130 & 100 & 109 & 97 & 79 & 124 & $D$ \\
\hline & & $1930-32$ & 61 & 70 & 100 & 104 & 125 & *59 & ${ }^{*} 84$ & ${ }^{* 98}$ & $\bar{*} 108$ & *124 & 107 & $\overline{95}$ & 100 & $\overline{92}$ & 114 & 三. \\
\hline & & 1950 & 64 & 62 & 103 & 95 & 149 & 57 & 67 & 100 & 114 & 132 & 80 & 79 & 108 & 89 & 116 & న \\
\hline & \multirow{2}{*}{ Married Women } & $1930-32$ & 52 & 67 & 99 & $\overline{106}$ & 132 & $* 54$ & ${ }^{* 78}$ & $* 104$ & $* 104$ & $*^{* 121}$ & 95 & 100 & 108 & $\overline{81}$ & 94 & (Bredit) 1 \\
\hline & & 1950 & 43 & 52 & $\overline{104}$ & $\overline{107}$ & 166 & 57 & 72 & 101 & 106 & 138 & 120 & $\overline{94}$ & $\mid 104$ & 96 & 91 & $\begin{array}{l}(\text { Breesys) } \\
\text { (Ceryax) }\end{array}$ \\
\hline \multirow[b]{2}{*}{ Age $65+$} & Men & 1950 & 77 & 62 & 106 & 92 & 143 & 70 & 86 & 101 & 110 & 113 & 108 & 89 & 105 & 79 & 118 & $\infty$ \\
\hline & Married women & 1950 & 107 & 107 & 91 & $\overline{88}$ & 126 & 81 & 88 & 103 & 105 & 107 & 176 & 99 & 97 & 92 & 103 & 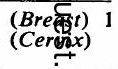 \\
\hline
\end{tabular}


TABLE IXA

STANDARDIZED MORTALITY RATIOS OF MEN AND OF MARRIED WOMEN AGED 20-64 IN SOCIAL SUB-CLASSES (ALL CAUSES, 1950)

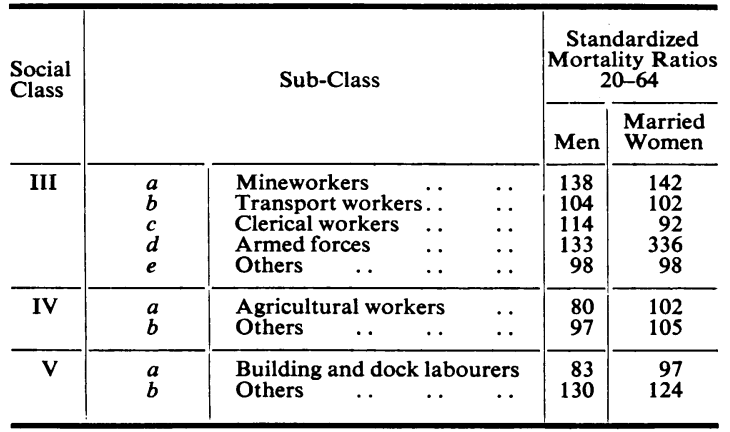

previous occasion on which this group was studied. However, only Social Class II was out of step; the others increased from Social Classes I to V.

The 1950 Classification of Occupations has introduced a number of major sub-divisions of Social Classes III, IV, and V. These "sub-classes" are purely occupational groupings within their respective social classes, and have no implied social grading such as that between the main classes. Table IXA shows the S.M.Rs of men and married women in nine sub-classes, and Table IXB shows in addition those for six large occupational groups for which population estimates happen to have been obtained from the One per cent. Sample Census tabulations. For men high S.M.Rs have been given by skilled mine workers, particularly hewers and getters (S.M.R. 154), members of the Armed Forces (133), and the unskilled workers in Social Sub-class Vb (130). In contrast are the low indices for engineering foremen (67), farmers (73), and builders' labourers (79).
TABLE IXB

STANDARDIZED MORTALITY RATIOS OF MEN AND OF MARRIED WOMEN AGED 20-64 IN SELECTED OCCUPATIONAL GROUPS

(ALL CAUSES, 1950)

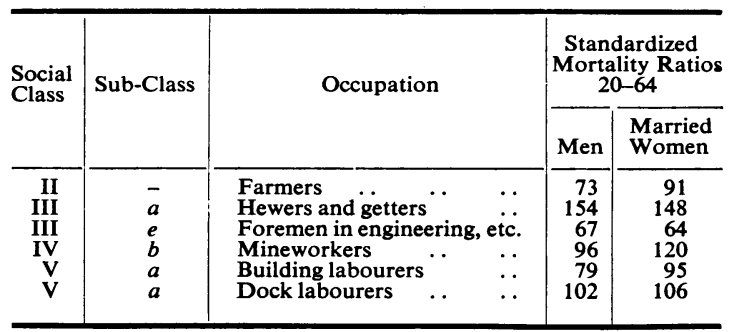

Among married women, high ratios are shown for the wives of mine workers and unskilled workers, suggesting that the high mortality risks of their husbands may be of social rather than of purely occupational origin. The S.M.R. of 336 for wives of members of the Armed Forces is artificially inflated and should be disregarded.

Individual Causes of Death (Table X).-Mortality from over thirty causes of death has been tabulated for 1950; Table X shows how the results for a few of these causes compare with earlier findings. The P.M.Rs at age 65 and over included in this Table are "Proportionate Mortality Ratios", viz. the proportion of deaths at age 65 and over attributed to the cause in question in a given social class expressed as a percentage of the corresponding proportion in all classes. Proportionate ratios have been used because ratios calculated upon the enumerated populations in the various occupational groups tend to be unreliable at advanced ages, chiefly owing to confusion between "unoccupied" and "retired".

\begin{tabular}{|c|c|c|c|c|c|c|c|c|c|c|c|c|c|c|c|c|c|c|c|c|c|c|c|c|c|c|c|c|}
\hline \multicolumn{4}{|c|}{ and Cervix Uteri } & \multicolumn{5}{|c|}{ Leukaemia } & \multicolumn{5}{|c|}{ Coronary Heart Disease $†$} & \multicolumn{5}{|c|}{$\begin{array}{l}\text { Myocardial } \\
\text { Degenerationt }\end{array}$} & \multicolumn{5}{|c|}{ Bronchitis } & \multicolumn{5}{|c|}{ Diabetes Mellitus } \\
\hline \multirow[t]{4}{*}{ II } & III & IV & V & $\mathbf{I}$ & II & III & IV & $\mathbf{V}$ & $\mathbf{I}$ & II & III & IV & $\mathbf{V}$ & $\mathbf{I}$ & II & III & IV & $\mathbf{V}$ & I & II & III & IV & $\mathbf{v}$ & I & II & III & IV & V \\
\hline & & & & - & - & - & - & - & - & - & 一 & 一 & 一 & 一 & 一 & - & - & 一 & 26 & 55 & 94 & 121 & 177 & 125 & 145 & 92 & 75 & 66 \\
\hline & & & & 153 & 125 & 96 & 94 & 85 & 237 & 148 & 95 & 66 & 67 & 77 & 92 & 94 & 105 & 122 & 31 & 57 & 91 & 124 & 156 & 122 & 155 & 95 & 82 & 69 \\
\hline & & & & 153 & 101 & 107 & 81 & 88 & 150 & 110 & 104 & 79 & 89 & 67 & 82 & 97 & 98 & 137 & 33 & 53 & 97 & 103 & 172 & 167 & 97 & 97 & 91 & 108 \\
\hline 116 & 103 & 84 & 82 & 167 & 118 & 107 & 76 & 76 & 157 & 126 & 93 & 85 & 88 & 54 & 75 & 99 & 110 & 129 & 27 & 56 & 99 & 119 & 155 & 56 & 89 & 104 & 108 & 106 \\
\hline \multirow[t]{2}{*}{$\begin{array}{r}100 \\
69 \\
\end{array}$} & $\begin{array}{r}106 \\
98\end{array}$ & $\begin{array}{r}76 \\
109\end{array}$ & $\begin{array}{r}97 \\
150 \\
\end{array}$ & 145 & 73 & 110 & 91 & 95 & 92 & 93 & 101 & 100 & 108 & 66 & 67 & 98 & 120 & 134 & 33 & 48 & 100 & 130 & 152 & 86 & 88 & 98 & 109 & 117 \\
\hline & & & & 235 & 118 & 94 & 94 & 65 & 150 & 116 & 101 & 85 & 81 & 87 & 99 & 98 & 111 & 99 & 50 & 72 & 103 & 107 & 130 & 130 & 139 & 100 & 78 & 72 \\
\hline $\begin{array}{r}113 \\
93\end{array}$ & $\begin{array}{l}105 \\
105\end{array}$ & $\begin{array}{l}77 \\
89\end{array}$ & $\begin{array}{r}83 \\
113\end{array}$ & 118 & 59 & 109 & 91 & 145 & 128 & 108 & 100 & 91 & 91 & 72 & 96 & 99 & 110 & 104 & 45 & 78 & 98 & 117 & 129 & 65 & 96 & 96 & 106 & 126 \\
\hline
\end{tabular}


Ratios calculated upon less than fifty actual deaths are italicized to indicate that their significance is uncertain.

Respiratory Tuberculosis.-For men aged 20-64 the steeply rising gradient from Social Class I to $\mathrm{V}$ seen in 1921-23 and 1930-32 has been repeated in 1950, but with the ratios for Social Classes II and IV rather lower than those for Social Classes I and III respectively. The P.M.Rs for elderly men show the same pattern. The gradient for married women aged 20-64 has remained steep and regular. At age 65 and over the deaths of married women from tuberculosis are few and the ratios are erratic.

Cancer of the Stomach.-Each of the series of ratios indicates a regular gradient of increasing mortality from Social Class I to V. The steepness of the gradient has remained unchanged since 1921-23.

Cancer of the Lung.-In the two previous analyses the evidence for an association between cancer of lung and social class was somewhat equivocal, but the 1950 figures for men aged 20-64 seem to suggest a rising gradient from Social Class $I$ to $V$. There are no signs, however, of a similar gradient amongst married women nor amongst men aged 65 and over.

Cancer of the Breast and Cervix Uteri.-The first of these two conditions displays a definite downward gradient from Social Class I to V for married women in both of the age groups shown. The second condition displays an opposite tendency, with the lowest mortality in the married women of Social Class I and the highest mortality in Social Class V. Cancer of these two sites is known to be correlated with child bearing; mortality from cancer of the breast is lower and from cancer of the cervix higher in women who have borne children than in those who have not, the number of children borne being also important. It is likely therefore that the much higher fertility of Social Classes IV and V helps to explain the mortality pattern of these two diseases. Whether it is the only reason cannot at present be said.

Leukaemia.-This is one of the diseases that shows a downward gradient from Social Class I to Social Class V, in both sexes, though many of the ratios shown in the Table are based on inadequate numbers. Better diagnosis in Social Class I than in Social Class V may be the reason; this may also explain the steady increase year by year in the numbers of deaths that are being recorded, but this is uncertain.

Coronary Heart Disease (Fig. 3).-In 1930-32 mortality from this cause in both sexes was higher in Social Classes I and II than in Social Classes IV and V.
In 1950 this gradient is still quite evident for men and for elderly married women, but for some unexplained reason the ratios for women aged 20-64 are graduated in the opposite direction, i.e. they rise upwards from Social Class I to $\mathrm{V}$ instead of declining. Possible reasons to account for the male gradient pattern include social class and occupational differences in death certificate terminology, in mental stress, in dietary habits, and in physical activity. Probably the last two factors are most important.
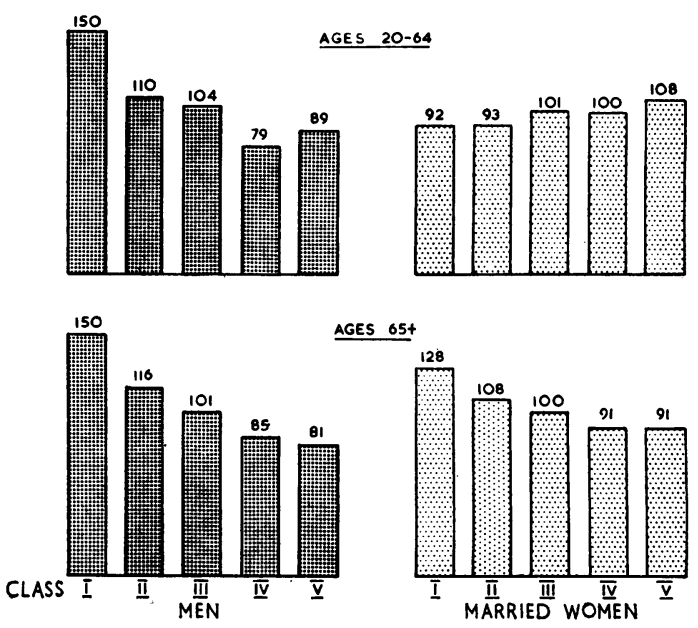

FIG. 3.-Coronary heart disease. Standardized mortality ratios of men and married women at ages 20-64, and proportionate mortality ratios at ages 65 and over, by social class (1950).

Myocardial Degeneration.-The mortality ratios for this condition amongst men aged 20-64 run in the opposite direction to those for coronary disease, being lowest in Social Class I increasing to Social Class V; the gradient for women is the same as that for men. At age 65 and over the same tendency persists, but the ratios are not quite as high in Social Class V as might be expected.

Bronchitis.-This disease gives the steepest and most uniform social class mortality gradient of all, with mortality at ages $20-64$ roughly five times higher in Social Class V than Social Class I. Clearly this is something that has to be taken into account in any studies of geographical variations in the incidence of bronchitis in relation to other factors such as climate or atmospheric pollution.

Diabetes Mellitus.-This condition has been included in order to show that the sex difference in the social class mortality gradient observed in 1930-32 has persisted in 1950. For men mortality is 
highest in Social Class I and declines towards Social Class .V. In women the gradient runs in the opposite direction.

Pneumonia, Suicide, Ulcer of Stomach, Ulcer of Duodenum (Fig. 4). - The pattern of mortality from pneumonia in 1950 was very similar to that from bronchitis, whereas the suicide ratios gave a U-shaped distribution. Mortality from gastric ulcer and duodenal ulcer contrasted strangely, the former showing a uniform social class gradient while the latter had its lowest death rates in Social Classes II and IV.

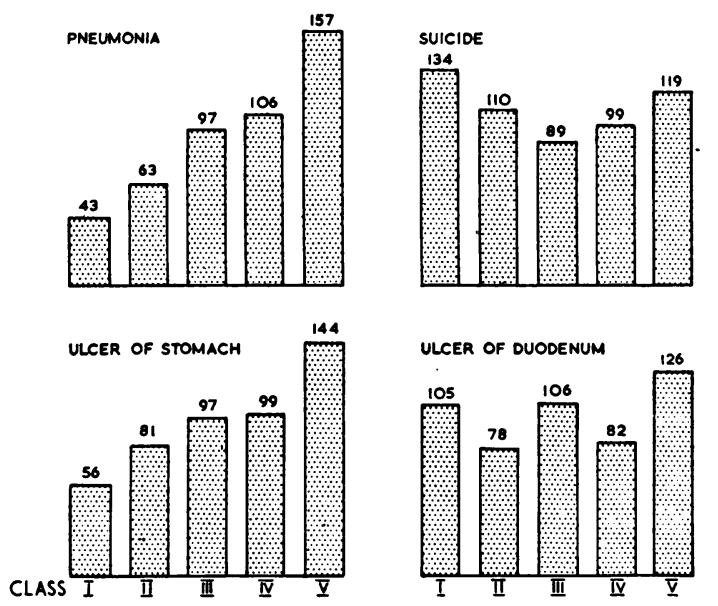

FIG. 4.-Standardized mortality ratios of men aged 20-64, by social class (1950).

\section{STILLBIRTHS AND INFANT MORTALITY}

The infant mortality rate, as has often been pointed out, is a sensitive index of social conditions, particularly as regards the post-neonatal period, i.e. from 4 weeks of age up to 1 year, where, as

TABLE XI

COMPARATIVE RATIOS OF STILLBIRTHS, NEONATAL (UNDER 4 WEEKS) AND POST-NEONATAL (4 WEEKS TO 1 YEAR) INFANT MORTALITY, BY SOCIAL CLASS OF FATHER. (LEGITIMATE ONLY)

\begin{tabular}{l|l|l|l|l|l|l}
\hline \multirow{2}{*}{ Mortality } & \multirow{2}{*}{ Year } & \multicolumn{5}{c}{$\begin{array}{c}\text { Social Class } \\
\text { (All Classes }=100 \text { ) }\end{array}$} \\
\cline { 2 - 5 } & & I & II & III & IV & V \\
\hline \multirow{2}{*}{ Stillbirths } & 1939 & 67 & 92 & 98 & 104 & 110 \\
& 1950 & 75 & 87 & 99 & 109 & 117 \\
\hline \multirow{2}{*}{ Neonatal } & 1921 & 69 & 83 & 99 & 108 & 109 \\
& $1930-32$ & 72 & 90 & 97 & 106 & 108 \\
& 1950 & 71 & 90 & 97 & 109 & 121 \\
\hline \multirow{3}{*}{ Post-neonatal } & 1921 & 33 & 60 & 95 & 117 & 133 \\
& $1930-32$ & 35 & 57 & 90 & 111 & 142 \\
& 1950 & 44 & 54 & 94 & 124 & 168 \\
\hline
\end{tabular}

Table XI shows, the death rate is persistently four times higher in Social Class V than in Social Class I. It is worth noting that, in spite of the tremendous reduction in infant mortality rates during the past 30 years, there has been no narrowing of the difference between the various social classes, i.e. no tendency for the gradient to become less steep.

There has likewise been no tendency for the social class differences in stillbirth and neonatal mortality rates (deaths under 4 weeks) to become less in recent years. As Fig. 5 illustrates, however, the gradient is much less steep for stillbirths and neonatal deaths than for deaths occurring later in the first year.

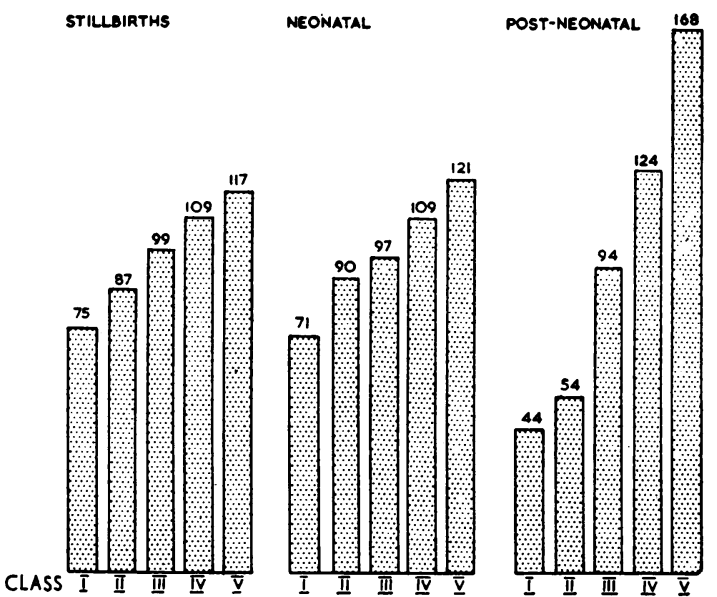

Fig. 5.-Comparative ratios of stillbirths, neonatal (under 4 weeks). and post-neonatal (4 weeks to 1 year) infant mortality by social class (1950).

Table XII indicates that a similar social class differentiation of post-neonatal mortality occurred in various parts of the country, but suggests that the comparative ratio for Social Class I was a little higher in the South of England and in the rural areas throughout the country than it was elsewhere.

TABLE XII

COMPARATIVE RATIOS OF POST-NEONATAL (4 WEEKS TO 1 YEAR) INFANT MORTALITY, BY SOCIAL CLASS IN REGIONAL AND DENSITY AGGREGATES, 1950

\begin{tabular}{|c|c|c|c|c|c|c|}
\hline \multirow{2}{*}{\multicolumn{2}{|c|}{ Aggregates }} & \multicolumn{5}{|c|}{$\begin{array}{c}\text { Social Class } \\
(\text { All Classes }=100)\end{array}$} \\
\hline & & I & II & III & IV & $\mathbf{V}$ \\
\hline $\begin{array}{l}\text { North } \\
\text { Midland and East } \\
\text { South } \\
\text { Wales }\end{array}$ & $\begin{array}{l}\cdots \\
\cdots \\
\cdots\end{array}$ & $\begin{array}{l}33 \\
48 \\
63 \\
30\end{array}$ & $\begin{array}{l}51 \\
60 \\
58 \\
52\end{array}$ & $\begin{array}{l}90 \\
95 \\
98 \\
95\end{array}$ & $\begin{array}{l}122 \\
119 \\
116 \\
120\end{array}$ & $\begin{array}{l}157 \\
168 \\
165 \\
157\end{array}$ \\
\hline $\begin{array}{l}\text { Conurbations } \\
\text { Other urban areas } \\
\text { Rural areas }\end{array}$ & $\begin{array}{l}\cdots \\
\cdots\end{array}$ & $\begin{array}{l}44 \\
36 \\
62\end{array}$ & $\begin{array}{l}47 \\
53 \\
66\end{array}$ & $\begin{array}{l}95 \\
90 \\
95\end{array}$ & $\begin{array}{l}121 \\
128 \\
122\end{array}$ & $\begin{array}{l}172 \\
165 \\
149\end{array}$ \\
\hline
\end{tabular}


Some of the most frequently certified causes of infant mortality are listed in Table XIII, more or less in order of steepness of social class gradient. The infections come first, viz. whooping cough, gastro-enteritis, and pneumonia, with rates more than five times higher in Social Class $V$ than in Social Class I. In contrast, at the foot of the list come congenital malformations and haemolytic disease, which show only relatively small differences between the mortality rates in one social class and another.

TABLE XIII

COMPARATIVE RATIOS OF INFANT MORTALITY (DEATHS UNDER 1 YEAR) FROM EIGHT SELECTED CAUSES, BY SOCIAL CLASS, 1950

\begin{tabular}{|c|c|c|c|c|c|c|}
\hline \multirow{2}{*}{\multicolumn{2}{|c|}{ Cause of Death }} & \multicolumn{5}{|c|}{ Social Class } \\
\hline & & I & II & III & IV & $\mathbf{V}$ \\
\hline $\begin{array}{l}\text { Whooping cough } \\
\text { Gastro-enteritis ... } \\
\text { Pneumonia } \\
\text { Accidental mechanical }\end{array}$ & $\begin{array}{l}\cdots \\
\cdots\end{array}$ & $\begin{array}{l}20 \\
28 \\
36\end{array}$ & $\begin{array}{l}33 \\
41 \\
53\end{array}$ & $\begin{array}{r}100 \\
92 \\
89\end{array}$ & $\begin{array}{l}120 \\
127 \\
127\end{array}$ & $\begin{array}{l}173 \\
183 \\
176\end{array}$ \\
\hline $\begin{array}{ll}\text { suffocation } & \ldots \\
\text { Prematurity } & \ldots \\
\text { Birth injury } & \text {.. } \\
\text { Congenital malformation } \\
\text { Haemolytic disease }\end{array}$ & $\begin{array}{l}\cdots \\
\ddot{n} \\
\cdots\end{array}$ & $\begin{array}{l}59 \\
59 \\
68 \\
80 \\
90\end{array}$ & $\begin{array}{r}46 \\
81 \\
97 \\
83 \\
110\end{array}$ & $\begin{array}{r}87 \\
97 \\
100 \\
102 \\
99\end{array}$ & $\begin{array}{r}118 \\
112 \\
114 \\
110 \\
96\end{array}$ & $\begin{array}{r}182 \\
129 \\
98 \\
109 \\
108\end{array}$ \\
\hline
\end{tabular}

\section{CONCLUSION}

As a post-script to this abridged review of occupational and social class mortality variations in England and Wales, a word may be added about the value of this kind of analysis. To tabulate one or several years' deaths by sex, age, occupation, and cause, and to calculate corresponding mortality rates is a big undertaking which could only be justified if the results were really worth having and served a useful purpose for administration or for research. On what grounds, then, are these large occupational mortality analyses justifiable?

Greenwood (1948) certainly thought them worth while when he described them as "the most valuable single instrument of socio-medical research our national armoury contains".

It cannot be claimed that our occupational mortality studies have revealed many specific industrial hazards that were not already known. The sand-blasting risk, for instance, was not discovered by a revelation in the official mortality tables that those who followed this occupation were subject to an exceptionally high mortality. In respect of occupations such as this which have a well-known special hazard the tabulations have confirmed rather than discovered the danger. In addition, however, they have allowed comparisons to be made from time to time and from one occupation to another. Sand-blasting, we know, is or was dangerous: but is it, or was it, more dangerous than hotel-keeping? In 1930-32 it was very much more dangerous, the respective standardized mortality ratios being 304 and 155. Coal gas workers and medical practitioners, who also suffer certain occupational risks, had S.M.Rs of 115 and 106, but the Anglican clergy, who apparently follow a less dangerous occupation, had a S.M.R. of only 69 . We are thus given the opportunity of seeing different occupations in perspective so that the relative risk can be appraised.

By grouping together occupations that seem to enjoy much the same living standards, we are able to show, as Stevenson has already pointed out (Registrar-General, 1927), that "mortality is influenced more by the conditions of life implied by various occupations than by the direct occupational risks entailed"; and this approach to the study of mortality variations has been greatly advanced by the decision in 1930-32 to take account also of the mortality of married women. The cynic may ask what, having shown that a disease is closely correlated with adverse living conditions, we propose to do about it, for it is admittedly beyond the ordinary powers of doctors to transfer their patients from Social Class V to Social Class I and so to relieve them of some of their bronchitis, tuberculosis, and myocardial degeneration (though increasing thereby their risk of coronary thrombosis). But this is the wrong approach. Having discovered that mortality from a disease is influenced to a significant degree by so-called social conditions, the next step is to study these conditions in detail to determine precisely by what mechanism the behaviour of a disease differs in different groups of people, or in what the advantages of one group consist. It may even be practicable, having recognized that the risk from a disease is greater in one group than another, to reduce the risk by taking special precautions with the vulnerable group.

These occupational and social class mortality studies also provide additional information about epidemiology and the natural history of disease. The observation that coronary disease kills men in professional and managerial occupations much more than those doing unskilled work, does not reveal the cause or causes of the disease, but has at least provided some useful leads.

There is little doubt that these extensive occupational mortality studies have a fundamental value as instruments of medical research, and, despite their various special limitations, it is probable that such studies will be needed periodically for a long time to come. 


\section{SUMMARY}

(1) An analysis is described of social class mortality in England and Wales in 1950, based upon the 1951 Census One per cent. Sample Tables.

(2) Compared with previous studies, mortality rates in Social Class II (men and married women) and Social Class IV (men only) are unexpectedly low.

(3) Social class gradients for certain individual causes of death are described.

(4) The social class gradient of infant mortality is found to be as steep in 1950 as it was 30 years earlier.

\section{REFERENCES}

Bertillon, J. (1889). “Annuaire statistique de la ville de Paris", p.186.

Daric, J. (1949). "Mortalité, profession, et situation sociale", Population, Paris, 4, 671. Republished in English in U.S. Public Health Service (1951) "Vital Statistics-Special Reports", vol. 33, No. 10.

Dublin, L. I. (1917). Bulletin of U.S. Bureau of Labor Statistics, No. 207, "Causes of Death by Occupation".
Dublin, L.I., and Vane, R. J. (1930). Ibid., No. 507. (1947). Monthly Labor Review, 64, 1003.

General Register Office (1951). "Classification of Occupations, 1950". Sample Tables". (1952). "Census 1951 Great Britain. One per cent.

Greenwood, M. (1948). "Some British Pioneers of Social Medicine", p. 79. Oxford University Press, London.

Huber, M. (1912). Bull. de la Statistique générale de la France, 1, 402.

Morris, J. N., and Heady, J. A. (1953). Brit. J. industr. Med., 10, 245.

Registrar-General of England and Wales (1855). "14th Annual Report (1851)".

(1913). "74th Annual Report (1911)".

- (1923). "Suppl. to 75th Annual Report. Mortality of Men in Certain Occupations in 1910, 1911, and 1912". Part IV.

(1927). "Decennial Supp. 1921. Occupational Mortality". Part II.

Mortality" Part I".

Stevenson, T. H. C. (1923). Biometrika, 15, 382.

(1928). J. roy. Statist. Soc., 91, 207.

Stocks, P. (1938). Ibid., 101, 669.

Villermé, L. R. (1840). "Tableau de l'état physique et moral des ouvriers", 2 vols. Renouard, Paris.

Whitney, J. S. (1934). "Death Rates by Occupation, based on Data of the U.S. Census Bureau, 1930". National Tuberculosis Association, New York. 